TITLE:

\title{
Fluorescence distribution pattern allows to distinguish two species of Eugymnanthea (Leptomedusae: Eirenidae)
}

\section{AUTHOR(S):}

Kubota, Shin; Pagliara, Patrizia; Gravili, Cinzia

\section{CITATION:}

Kubota, Shin ...[et al]. Fluorescence distribution pattern allows to distinguish two species of Eugymnanthea (Leptomedusae: Eirenidae). Journal of the Marine Biological Association of the United Kingdom 2008, 88(8): 1743-1746

ISSUE DATE:

2008-12-18

URL:

http://hdl.handle.net/2433/187919

\section{RIGHT:}

(c) Marine Biological Association of the United Kingdom 2008 


\title{
Fluorescence distribution pattern allows to distinguish two species of Eugymnanthea (Leptomedusae: Eirenidae)
}

\author{
SHIN KUBOTA ${ }^{1}$, PATRIZIA PAGLIARA ${ }^{2}$ AND CINZIA GRAVILI ${ }^{2}$ \\ ${ }^{1}$ Seto Marine Biological Laboratory, Field Science Education and Research Center, Kyoto University, Shirahama, Nishimuro, \\ Wakayama 649-2211, Japan, ${ }^{2}$ Department of Biological and Environmental Science and Technology, University of Salento, Lecce, \\ Via per Monteroni 73100 Lecce, Italy
}

\begin{abstract}
The auto-fluorescence patterns of the medusae observed under a fluorescent microscope with blue light excitation allows to distinguish two species of Eugymnanthea, this even when they are still attached to the hydroid as small medusa buds despite the occurrence of a sex-dependant pattern in E. japonica. A total of four distribution patterns of green fluorescence, including non-fluorescence, could be found. Three of them are found in E. japonica, called 'subumbrellar fluorescence type' except for non-fluorescence, while another type is found in E. inquilina, called 'umbrellar margin fluorescence type'. During the short life of the medusa the latter type remained invariable for up to six days in E. inquilina, while the pattern observed for up to seven days in E. japonica changed sometimes, but it always remained distinguishable from the pattern found in $\mathrm{E}$. inquilina. Therefore, the fluorescence pattern is a reliable taxonomic character. Fluorescence was not found in unfertilized eggs, planulae $2-8$ days old, parthenogenetically produced larvae, or in the hydroids of the two species. The auto-fluorescent and possible bioluminescent tissues of these Eugymnanthea medusae could have some unknown biological significance.
\end{abstract}

Keywords: fluorescence distribution patterns, Eugymnanthea species, various developmental stages

Submitted 9 August 2007; accepted 24 June 2008; first published online 23 September 2008

\section{INTRDDUCTIDN}

Eugymnanthea is a commensal hydroid associated mainly with Mytilus galloprovincialis and other bivalves inhabiting shallow waters. It occurs in the Mediterranean Sea (E. inquilina) and around the Japanese Sea (E. japonica) (Kubota, 1989, 1992, 2004; Piraino et al., 1994; Rayyan et al., 2002; Baba et al., 2007). The life cycle of both species comprises a benthic hydroid and a planktonic medusa stage. Species of Eugymnanthea have a simplified medusa that is released with already formed gonads. They only spend a very short time in the plankton and they die after spawning. The two species of Eugymnanthea, which evolved as the most derived bivalveinhabiting hydrozoans from an ancestral Eirene and/or Eutima-like progenitor, resemble each other both in the hydroid and medusa stages. The similarity is likely due to a parallel, progenetic evolution, which also explains some of the subtle morphological differences (Kubota, 2000). Individuals from the Mediterranean and Japan are very similar at any developmental stage, but by examining a large number of specimens of several populations, Kubota $(1991,2004)$ found some morphological differences of the medusae that permit to discriminate the two species. These are: presence of a manubrium and a smaller number of statoliths per statocyst (usually 1) in the Japanese form, versus the absence of a manubrium and several statoliths per statocyst (usually 2 or 3 ) in the Mediterranean form.

Corresponding author:

S. Kubota

Email: shkubota@medusanpolyp.mbox.media.kyoto-u.ac.jp
Govindarajyan et al. (2005) demonstrated that they are two distinct species by using a cross-fertilization test, a mesogloeal adhesion and spreading test, and by $16 \mathrm{~S}$ rDNA sequence comparisons. In the present study, we describe a new morphological character that allows both species to be distinguished, i.e. different distribution pattern of green auto-fluorescence.

\section{MATERIALS AND METHDDS}

A total of 77 medusae of both sexes of Eugymnanthea inquilina were examined, originating from 53 specimens of Mytilus galloprovincialis Lamarck from Taranto (39 specimens) and Lago Fusaro, the type locality (14 specimens), one specimen of Mytilaster minimus (Poli) from Taranto, and eight specimens of Chylamys glabra (Linnaeus) from Taranto. They were collected from October 1999 to January 2000 (Kubota, 2004). Mytilus galloprovincialis associated with hydroids were kept in the biological laboratory of Lecce (University of Salento) from mid-October 1999 to mid-March 2000 at $23^{\circ} \mathrm{C}$ and a 15hL:9hD photoperiod. They were kept in several thousand $\mathrm{ml}$ glass or plastic containers with natural seawater taken from rocky coasts near Porto Cesareo or from inside the port of Porto Cesareo and fed with newly hatched Artemia nauplii. The seawater $(38-40 \mathrm{ppt})$ was changed nearly every day and almost all of the released mature medusae were examined before they spawned in early morning. A Zeiss Standard Axioplan microscope equipped with a halogen lamp ( $\mathrm{Hg} 100)$ light and blue light excitation with a BP 485/20 excitation filter, an FT 510 chromatic beam splitter, and an LP 520 barrier filter were used to observe the slides prepared from 
each sample. Hydroids with or without a medusa bud were removed from the bivalves, and reared and examined under the microscope as described above.

A total of 474 medusae of both sexes of Eugymnanthea japonica Kubota, 1979 were examined, originating from 47 specimens of Mytilus galloprovincialis from Shirahama (27 specimens) and Atami, near to the type locality Shimoda (20 specimens), Japan, which were reared and examined as described above (Kubota, 2004).

Medusae of both species ( 12 E. japonica and 4 E. inquilina) were reared until they died and the change of the fluorescence pattern was examined every day. Unfertilized eggs that were not older than a few hours and planulae obtained after conspecific crossings (see Govindarajan et al., 2005) of both Eugymnanthea species were examined similarly together with parthenogenetically produced larvae if present.

\section{RESULTS}

The presence and type of green fluorescence is described in relation to the developmental stage (Tables $1 \& 2$ ). The changes of the fluorescence pattern observed during the life span of the medusa, maximally for seven days, are summarized in Table 3.

\section{Medusa}

The auto-fluorescence pattern observed in the medusae of $E$. inquilina (Figure 1A, B) and E. japonica (Figure $1 \mathrm{C}, \mathrm{D}$ ) was constantly different, showing 'umbrellar margin fluorescence type' in the former and a 'subumbrellar fluorescent type' in the latter. In addition, in E. inquilina only the peripheral part of gonads showed an auto-fluorescence (Figure 1B).

Two subtypes of fluorescence distribution were found in $E$. japonica, namely the subumbrellar fluorescence type confined to individual auto-fluorescent photocytes (Figure $1 \mathrm{D}$ ) and another type with a uniform overall auto-fluorescence (Table 2). No pattern-variation was found for E. inquilina (Tables $1 \& 2$; Figure $1 \mathrm{~B}$ ). Only a small fraction of E. japonica medusae $(2.7 \%$ in 474$)$ showed no fluorescence at all (Table 2). Summarizing, we observed four different patterns in the medusae of Eugymnanthea.

The type of subpattern found in E. japonica seems to depend somewhat on the sex as females had no autofluorescent particles, thus the subumbrella has a brilliant, uniform fluorescence (92.6\% in 394 examined females), while the auto-fluorescence in males tends to be concentrated into auto-fluorescent particles $(63.6 \%$ in 33 males examined)

During the short life span of the medusa of E. japonica, maximally a week, a change of fluorescence pattern was detected in three out of four examined males (from the subumbrellar type to absence type or vice versa), and the changes were all irreversible (Table 3). The changes did not correlate with the age of the medusa or with senescence. Females of E. japonica did not change their pattern (examined in eight individuals; Table 3). In E. inquilina the fluorescence pattern was constant in all of the examined individuals, i.e. in two males and two females.

Table 1. Presence of fluorescence in various developmental stages of two species of Eugymnanthea.

\begin{tabular}{|c|c|c|}
\hline \multirow[t]{2}{*}{ Developmental stage } & \multicolumn{2}{|c|}{ Appearance of fluorescent type in } \\
\hline & E. inquilina & E. japonica \\
\hline Medusa (see Table 2) & $\begin{array}{l}1 \text { type } \\
\left(77,3^{*}, 2^{* *}\right)\end{array}$ & $\begin{array}{l}2 \text { types }+ \text { absent } \\
(474,1,2)\end{array}$ \\
\hline Unfertilized eggs within several hours after spawning & $\begin{array}{l}\text { Absent } \\
(82 \text { from } 9 \text { females, } 1,1)\end{array}$ & $\begin{array}{l}\text { Absent } \\
\text { (203 from } 26 \text { females, } 1,2 \text { ) }\end{array}$ \\
\hline Planula & $\begin{array}{l}\text { Absent } \\
\left(83_{-}-8 \text { days old, } 1 \text { pair, } 1,1\right)\end{array}$ & 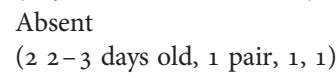 \\
\hline Parthenogenetic larva & Not appeared & $\begin{array}{l}\text { Absent } \\
\text { (2 1-day-old, } 1 \text { pair, 1, 1) }\end{array}$ \\
\hline Hydroid & $\begin{array}{l}\text { Absent } \\
\left(137,3^{*}, 2^{* *}\right)\end{array}$ & $\begin{array}{l}\text { Absent } \\
(116,1,2)\end{array}$ \\
\hline Medusa bud & $\begin{array}{l}\text { Same as medusa } \\
\left(97,3^{*}, 1\right)\end{array}$ & $\begin{array}{l}\text { Same as medusa } \\
(103,1,2)\end{array}$ \\
\hline
\end{tabular}

*, Mytilus galloprovincialis (53 specimens), Mytilaster minimus (1 specimen), and Chlamys glabra (8 specimens); **, Taranto and Lago Fusaro.

$\mathrm{N}$, number of host sp. examined, number of localities surveyed.

Table 2. Fluorescent subtype of medusa and its frequency in the number of individuals examined in the two species of Eugymnanthea.

\begin{tabular}{|c|c|c|}
\hline Distribution of fluorescence & $\begin{array}{l}\text { E. inquilina collected from } 3 \text { host spp. } \\
\text { from } 2 \text { localities }\end{array}$ & $\begin{array}{l}\text { E. japonica collected from } 1 \text { host sp. } \\
\text { from } 2 \text { localities }\end{array}$ \\
\hline Subumbrella with photocysts & o & 21 males +26 females $+12^{*}$ \\
\hline Subumbrella without photocysts & o & 4 males +365 females $+33^{*}$ \\
\hline $\begin{array}{l}\text { Umbrellar margin (marginal } \\
\text { bulbs with photocysts) and } \\
\text { peripheral part of gonads }\end{array}$ & $\begin{array}{l}34 \text { males }+16 \text { females }+ \\
10^{*}+17 \text { hermaphrodites }\end{array}$ & o \\
\hline Non-fluorescent & o & 8 males +3 females $+2^{*}$ \\
\hline
\end{tabular}

*, sex undetermined. 
Table 3. Change of fluorescent type in the life span of the medusa of the two species of Eugymnanthea.

\begin{tabular}{|c|c|c|}
\hline Fluorescence & $\begin{array}{l}\text { Number of medusae } \\
\text { examined }\end{array}$ & Age of change in days and/or state continuation \\
\hline \multicolumn{3}{|c|}{ E. japonica from Mytilus galloprovincialis collected from two localities } \\
\hline \multicolumn{3}{|c|}{ Changes } \\
\hline from subumbrella without photocysts to non-fluorescent & 1 male & Change on the 4 th day, then continued until the $5^{\text {th }}$ day \\
\hline from non-fluorescent to subumbrella without photocysts & 2 males & Change on the and day, then continued until the 3 rd day \\
\hline \multicolumn{3}{|l|}{ No changes } \\
\hline subumbrella with photocysts & 1 male & For up to 3 days \\
\hline subumbrella without photocysts & 8 females & For up to 4-7 days \\
\hline \multicolumn{3}{|c|}{ E. inquilina from Mytilus galloprovincialis and Chlamys glabra collected from Taranto } \\
\hline \multicolumn{3}{|c|}{ No changes } \\
\hline umbrellar margin & 2 females & For up to 3 days \\
\hline umbrellar margin & 2 males & For up to 6 days \\
\hline
\end{tabular}
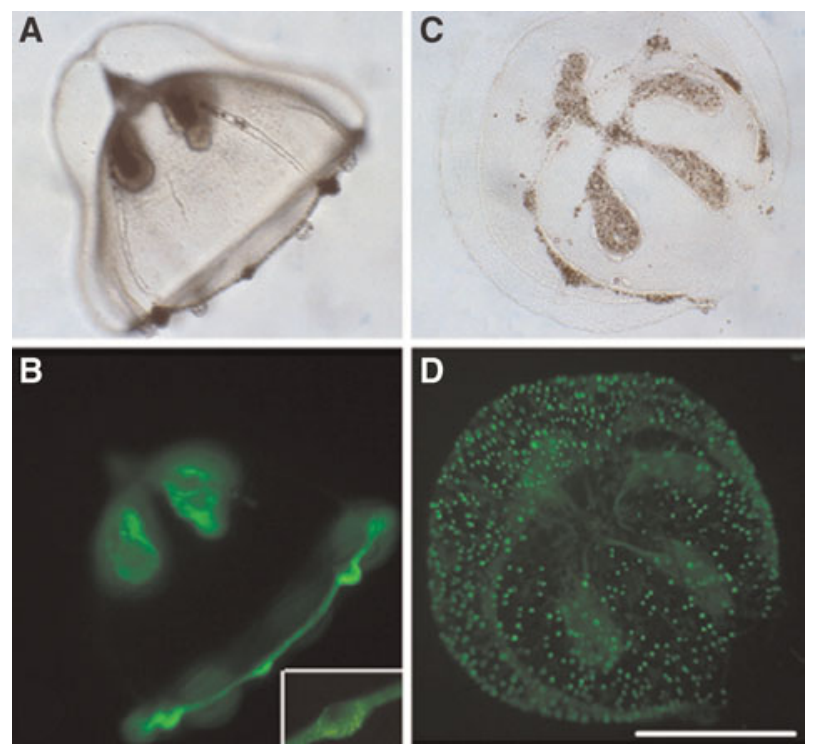

Fig. 1. Photomicrographs of medusa of (A, B) Eugymnanthea inquilina and $(\mathrm{C}, \mathrm{D})$ E. japonica. Auto-fluorescence image under blue light excitation $(\mathrm{B}, \mathrm{D})$ and transmitted light image $(\mathrm{A}, \mathrm{C})$ of same individuals. Scale bars: $0.5 \mathrm{~mm}$ except for inset in (B) that shows a marginal bulb.

\section{Medusa bud}

In E. inquilina medusa buds we could detect auto-fluorescence in the distal part of the bud in every one of the 97 examined individuals (Figure 2A, B), while in E. japonica the whole subumbrella showed a uniform fluorescence in all 103 examined medusa buds (Figure 2C, D; Table 1). The auto-fluorescence of the gonads in E. inquilina appeared only later, when the gonads were well developed.

\section{Eggs, planulae and hydroids}

The auto-fluorescence was completely absent in 285 (203 in E. japonica +82 in E. inquilina) unfertilized eggs, $10(2+8)$ $2-8$ days old planulae, even in two parthenogenetically produced larva of E. japonica, and $253(103+97)$ hydroids in the two Eugymnanthea species (Table 1).

\section{DISCUSSION}

We found that the auto-fluorescent distribution pattern of the medusa bud and the free medusa is a reliable taxonomic
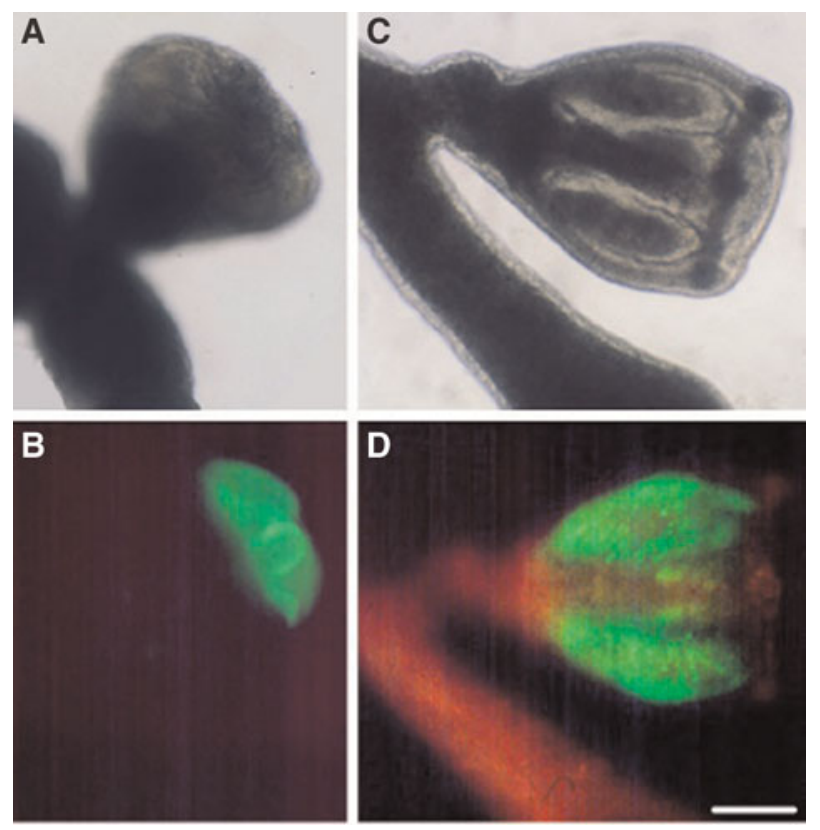

Fig. 2. Photomicrographs of medusa buds of (A, B) Eugymnanthea inquilina and (C, D) E. japonica. Auto-fluorescence image under blue light excitation $(\mathrm{B}, \mathrm{D})$ and transmitted light image $(\mathrm{A}, \mathrm{C})$ of same individuals of respective species. Scale bars: $0.1 \mathrm{~mm}$.

character, which permits to distinguish the two Eugymnanthea species, despite the occurrence of a sexdependant pattern in E. japonica. Such an auto-fluorescence pattern might also be useful for distinguishing other similar hydrozoan species, particularly for species evolved convergently or sibling species. As was pointed out by Morin \& Reynolds (1969, 1974), fluorescence microscopy is easily applied to living material without complicated, timeconsuming techniques. It is noteworthy that the fluorescent pattern is different in the two Anemonia species common to the Mediterranean Sea (Leutenegger et al., 2007).

Several studies have been carried out on natural bioluminescence produced by Cnidaria and Ctenophora due to the presence of natural bioluminescent compounds (Haddock \& Case, 1999; Haddock et al., 2001). Some photoproteins have been isolated from Hydrozoa: aequorin (Harvey, 1935; Davenport \& Nicol, 1955; Nicol, 1962; Shimomura, 2005) and obelin (Campbell, 1974; Vysotskii et al., 1990, 1993, 1995). Morin \& Reynolds (1974) found that in Obelia 
hydroids the distribution of the fluorescent regions correlates with the ability to produce bioluminescence and that it may have some functional significance. One eminent ecological example of fluorescent structures serving as lures is reported in an Erenna siphonophore that preys upon fish in deep waters (Haddock et al., 2005). The auto-fluorescent and possible bioluminescent tissues of present Eugymnanthea medusae could likewise have some unknown biological significance as pointed out by Morin (1983). It is noteworthy that in contrast to complete absence of auto-fluorescence in the eggs and planula larvae of the two species of Eugymnanthea, the eggs and embryos of many kinds of sea urchin display autofluorescence and the pluteus larvae emit green fluorescence (Nakamura et al., 2005) though their function is unknown.

\section{ACKNDWLEDGEMENTS}

We thank Drs Ferdinando Boero, Stefano Piraino, Christina Maria Buia, Genuario Belmonte, Antonio Terlizzi, Maria Pia Miglietta, Akio Murakami, and also Roberto Pagliara and Cataldo Pierri for their kind help with various ways of support during the study. Thanks are due to anonymous referees, and editors of JMBA for critical reading of the manuscript.

\section{REFERENCES}

Baba K., Miyazono A., Matsuyama K., Kohno S. and Kubota S. (2007) Occurrence and detrimental effects of the bivalve-inhabiting hydroid Eutima japonica on juvenile of the Japanese scallop Mizuhopecten yessoensis in Funka Bay, Japan: relationship to juvenile massive mortality in 2003. Marine Biology (Berlin) 151, 1977-1987.

Campbell A.K. (1974) Extraction, partial-purification and properties of obelin, calcium activated luminescent protein from hydroid Obelia geniculata. Biochemical Journal 143, 411-418.

Davenport D. and Nicol J.A.G. (1955) Luminescence in Hydromedusae. Proceedings of the Royal Society, Biological Sciences Series B 144, 399-411.

Govindarajan A.F., Piraino S., Gravili C. and Kubota S. (2005) Species identification of bivalve-inhabiting marine hydrozoans of the genus Eugymnanthea. Invertebrate Biology 124, 1-10.

Haddock S.H.D. and Case J.F. (1999) Bioluminescence spectra of shallow and deep-sea gelatinous zooplankton: ctenophores, medusae and siphonophores. Marine Biology (Berlin) 133, 571-582.

Haddock S.H.D., Rivers T.J., Robison B.H. (2001) Can coelenterates make coelenterazine? Dietary requirement for luciferin in cnidarian bioluminescence. Proceedings of the National Academy of Sciences of the United States of America 98, 11148-11151.

Haddock S.H.D., Dunn C.W., Pugh P.R. and Schnitzler C.E. (2005) Bioluminescent and red-fluorescent lures in a deep-sea shiphonophore. Science 309, 263.

Harvey E.N. (1935) Studies on bioluminescence. XIII. Luminescence in the coelenterates. Biological Bulletin. Marine Biological Laboratory, Woods Hole 41, 280-287.

Kubota S. (1989) Systematic study of a paedomorphic derivative hydrozoan Eugymnanthea (Thecata-Leptomedusae). Zoological Science 6, $147-154$.

Kubota S. (1991) Crossing-experiments between Japanese populations of three hydrozoans symbiotic with bivalves. Hydrobiologia 216/217, $429-436$.
Kubota S. (1992) Four bivalve-inhabiting hydrozoans in Japan differing in range and host preference. Scientia Marina 56, 149-159.

Kubota S. (2000) Parallel, paedomorphic evolutionary processes of the bivalve-inhabiting hydrozoans (Leptomedusae, Eirenidae) deduced from the morphology, life cycle and biogeography, with special reference to taxonomic treatment of Eugymnanthea. Scientia Marina 64, Supplement 1, 241-247.

Kubota S. (2004) Some new and reconfirmed biological observations in two species of Eugymnanthea (Hydrozoa, Leptomedusae, Eirenidae) associated with bivalves. Biogeography 6, 1-5.

Leutenegger A., Kredel S., Gundel S., D'Angelo C., Salih A. and Wiedenmann J. (2007) Analysis of fluorescent and non-fluorescent sea anemones from the Mediterranean Sea during a bleaching event. Journal of Experimental Marine Biology and Ecology 353, 221-234.

Morin J.G. (1983) Coastal bioluminescence: patterns and functions. Bulletin of Marine Science 33, 787-817.

Morin J.G. and Reynolds G.T. (1969) Fluorescence and time distribution of photon emission of bioluminecent photocytes in Obelia geniculata. Biological Bulletin. Marine Biological Laboratory, Woods Hole 137, 410.

Morin J.G. and Reynolds G.T. (1974) The cellular origin of bioluminescence in the colonial hydroid Obelia. Biological Bulletin. Marine Biological Laboratory, Woods Hole 147, 397-410.

Nakamura S., Mikamori M., Hiramatsu M., Eura S., Takamoto H. and Watanabe M. (2001) Spectacular fluorescence emission in sea urchin larvae. Zoological Science 18, 807-810.

Nicol J.A.C. (1962) Animal luminescence. Advances in Comparative Physiology and Biochemistry 1, 217-273.

Piraino S., Todaro C., Geraci S. and Boero F. (1994) Ecology of the bivalve-inhabiting hydroid Eugymnanthea inquilina in the coastal sounds of Taranto (Ionian Sea, SE Italy). Marine Biology (Berlin) $118,695-703$.

Rayyan A., Christidis J. and Chintiroglou C.C. (2002) First record of the bivalve-inhabiting hydroid Eugymnanthea inquilina in the eastern Mediterranean Sea (Gulf of Thessaloniki, north Aegean Sea, Greece). Journal of the Marine Biological Association of the United Kingdom $82,851-853$.

Shimomura O. (2005) The discovery of aequorin and green fluorescent protein. Journal of Microscopy 217, 3-15.

Vysotskii E.S., Bondar V.S., Gitelson I., Petrunyaka V.V., Gamalei I.A. and Kaulin A.B. (1990) Extraction, some properties and application of obelin, calcium activated photopotein. In Jezowska-Trzebiatowska B., Kochel B., Slawinski J. and Sterk W. (eds) Biological luminescence. Singapore and New Jersey: World Scientific, pp. 386-395.

Vysotskii E.S, Trofimov K.P., Bondar V.S. and Gitelson J.I. (1993) Luminescence of $\mathrm{Ca}^{2+}$ activated photoprotein obelin initiated by $\mathrm{NaOCl}$ and $\mathrm{MnCl}_{2}$. Journal of Bioluminescence and Chemiluminescence 8, 301-305.

and

Vysotskii E.S., Trofimov C.P., Bondar V.S., Frank L.A., Markova S.V. and Illarionov B.A. (1995) $\mathrm{Mn}^{-2+-}$ activated luminescence of the photoprotein obelin. Archives of Biochemistry and Biophysics 316, 92-99.

\section{Correspondence should be addressed to:}

Shin Kubota

Seto Marine Biological Laboratory, Field Science Education and Research Center,

Kyoto University, Shirahama, Nishimuro, Wakayama 649-2211, Japan

email: shkubota@medusanpolyp.mbox.media.kyoto-u.ac.jp 